\title{
AIR CURED ALKALI ACTIVATED FLYASH MASONRY UNITS
}

\author{
Venugopal $K^{1}$, Radhakrishna ${ }^{2}$ \\ ${ }^{1}$ Research Scholar, Jain University, Bengaluru, India \\ venugopalk82@yahoo.co.in \\ ${ }^{2}$ Associate Professor, Department of Civil Engineering, $R V$ College of Engineering, Affiliated to Visvesvaraya \\ Technological University, Bengaluru, India \\ radhakrishna@rvce.edu.in
}

\begin{abstract}
Geopolymers belong to a category of non-conventional and non-Portland cement based cementitious binders and they are produced using industrial by products like fly ash and ground granulated blast furnace slag (GGBFS). This paper reports the development of geopolymer mortars for production of masonry units. The geopolymer mortars were prepared by mixing the mentioned by products with manufactured sand and a liquid mixture of sodium silicate and sodium hydroxide solutions. After curing at ambient conditions, the masonry units were tested for strength properties such as water absorption, initial rate of absorption, compression, bond-shear, and stress-strain behavior etc. It was observed that the flexural strength of the block is more than $2 \mathrm{MPa}$ and shear bond strength is more than 0.4MPa. It was found that the properties of geopolymer blocks were superior to the traditional masonry units. Hence they can be recommended for structural masonry.
\end{abstract}

Keywords: Fly Ash, GGBFS, M-Sand, Masonry Units, Strength Etc.

\section{INTRODUCTION}

The history of masonry construction is regarded as the beginning of civil engineering. Masonry is one of the oldest methods of construction which has been built for the aesthetics and durability. Masonry is building structure with individual units called as masonry units; it is well bonded by mortar between units. In the 19th century, Park Guell in Barcelona, a famous monument was built using reinforced masonry designed by Spanish architect Antoni Gaudi [1]. In the present construction masonry has been widely used in the construction of the residential buildings, commercial building and public buildings. Masonry structure would perform variety of functions like, supporting loads, dividing and subdividing the space, provide aesthetic appearance, thermal and acoustic insulations etc. The traditional types of masonry units are burnt clay bricks, hollow blocks, solid blocks and stabilized mud blocks. These masonry units are adopted based on requirements like, compressive strength, accessibility, cost and ease of construction [2]. The masonry mortar is used to bond the masonry units together. In India, there are about 1lakh brick manufacturing industries producing 140 billion bricks per year. It consumes around 400 million tonnes of top fertile soil. Also nearly 25 million tonnes coal and fossil fuel is required for burning of bricks and it is energy intensive material [3]. Brick industries are releasing annually $28 \%$ of sulphur oxide to the atmosphere which is one of the major air pollutants. Cement which is the main ingredient in the manufacture of cement concrete blocks produces considerable amount of carbon dioxide. It contributes nearly $7 \%$ of world's emission which leads into global warming [4].

Geopolymer is the term coined by Professor Joseph Davidovits for the family of high alkali binders formed in a reaction called as geopolymerization [5]. Geopolymers are the family of binders formed by using alkaline solutions and alumino silicates like fly ash, Ground granulated blast furnace slag (GGBFS), resulting in three dimensional aluminosilicate polymeric gel. Geopolymers are environmental friendly as they make use of industrial byproducts and eliminate the use of conventional cement.

Many researchers have reported that the utilization refractory concrete can be made using quartz sand, alumina powder, zeolites and rice husk using geopolymer [6-7]. The use of fly ash and GGBFS in concrete can result in achieving considerable compressive and split tensile, bond strength [8-14]. Different geopolymer composites can be made using geopolymers and phenomenological models can be developed to re-proportion them [15-20]. The use of 5$10 \%$ paper sludge by replacement of fine aggregates in fresh concrete can increase the compressive and tensile strength of geopolymer concrete [21-22].

The use of solid brick-pure lime mortar masonry prisms will exhibit 10 times more strength than the mortar [23]. It was found that the effect of freeze-thaw cycles on masonry, will not affect up to 150 cycles but after 150 cycles the bricks and mortar were damaged [24]. Study on properties of ready mix earth plastering mortar satisfied the German codal provisions and can be used as rehabilitation plaster for existing masonry structures [25-27].

Though there is considerable research reported on brick and block masonry, the production of these masonry units are not sustainable. Hence there is need to develop alternative masonry units, one of which can be geopolymer unit. This paper addresses the technology of making properties of geopolymer units. 


\section{RESEARCH SIGNIFICANCE}

The development of geopolymer masonry units is a relatively new concept, whereas, the research on geopolymer concrete is extensively reported. In case of geopolymer concrete, the use of alkaline salts is considerably high which may not be economically feasible always. The amount of alkaline salts can be considerably reduced in making these masonry units. Determination of strength and durability of these units will boost the confidence level of the field engineer. Thus the present study will be helpful to construction industry.

\section{MATERIALS AND METHODS}

The following materials were used to prepare geopolymer masonry blocks:

i. Class F Fly ash and GGBFS,

ii. Manufactured sand (M-sand)

iii. Recycled water,

iv. Sodium hydroxide and Sodium silicate.

Low calcium Class-F fly ash and ground granulated blast furnace slag (GGBFS) were used as binders. The specific gravity of fly ash and ground granulated blast furnace slag were 2.40 and 2.90 respectively. Manufactured sand was used as fine aggregates. The specific gravity of manufactured sand was 2.61. The fineness modulus of manufactured sand was found to be 3.45. Manufactured sands fall in zone-II. The details of mix proportions are shown in Tables 1.

The fly ash, GGBFS and M-sand were first mixed thoroughly in dry condition and then alkali solution was added to prepare fresh mortar. The geopolymer blocks were prepared by compressing the required amount of mortar and cured in open air without any special treatment. The masonry units were tested for water absorption, initial rate of waste absorption, density, flexural strength and shear bond strength. The compressive strengths were determined along with modulus of elasticity.

Table 1: Series designation and composition of block of $8 \mathrm{M}$

\begin{tabular}{|c|c|c|c|}
\hline \multicolumn{3}{|c|}{ Binder Composition [Fly ash : GGBFS]: } & $80: 20$ \\
\hline \multicolumn{4}{|c|}{ Molarity of sodium Hydroxide [M]: 8} \\
\hline $\begin{array}{c}\text { Series } \\
\text { Designation }\end{array}$ & $\begin{array}{c}\text { Mortar } \\
\text { Proportion } \\
\text { [Binder : M- } \\
\text { Sand] }\end{array}$ & $\begin{array}{c}\text { Alkaline } \\
\text { Proportion } \\
\text { [Hydroxide : } \\
\text { Silicate] }\end{array}$ & $\begin{array}{c}\text { Fluid- } \\
\text { Binder } \\
\text { Ratio } \\
\text { [F/B] }\end{array}$ \\
\hline GPB-1 & $1: 1$ & $1: 0$ & 0.20 \\
\hline GPB-2 & $1: 1$ & 1:0.5 & 0.20 \\
\hline GPB-3 & $1: 1$ & $1: 1$ & 0.20 \\
\hline GPB-4 & $1: 1$ & $1: 1.5$ & 0.20 \\
\hline GPB-5 & $1: 1$ & $1: 2$ & 0.20 \\
\hline GPB-6 & $1: 1$ & $1: 2.5$ & 0.20 \\
\hline
\end{tabular}

\section{RESULTS AND DISCUSSION}

The water absorption and density of the blocks was conducted as per IS 1077-1992 and it is tabulated in Table 2. According to codal provision the water absorption of blocks should be less than $20 \%$ and densities of blocks should be not more than $2.0 \mathrm{gm} / \mathrm{cc}$. It was found that the water absorption of the units rages from 9.0 to $10.5 \%$ which is considerably less compared to the traditional blocks. The density of the masonry units ranges from 1.78 to $1.89 \mathrm{~g} / \mathrm{cc}$ which are par with the traditional units.

Table 2: Water absorption and dry density tests for blocks

\begin{tabular}{|c|c|c|}
\hline Series Id. & $\begin{array}{c}\text { Water } \\
\text { Absorption [\%] }\end{array}$ & $\begin{array}{c}\text { Average Dry } \\
\text { Density [gm/cc] }\end{array}$ \\
\hline GPB-1 & 10.5 & 1.78 \\
\hline GPB-2 & 10.1 & 1.81 \\
\hline GPB-3 & 9.8 & 1.825 \\
\hline GPB-4 & 9.6 & 1.85 \\
\hline GPB-5 & 9 & 1.89 \\
\hline GPB-6 & 8.5 & 1.91 \\
\hline
\end{tabular}

Initial Rate of Absorption [IRA] of geopolymer blocks at 28 days is shown in Table 3 for various faces of immersion. IRA was found to be less than $5 \%$ of faces of immersions for the different series, which indicates that the masonry mortar will have good water retentivity [26].

Table 3: Initial Rate of Absorption [IRA] of geopolymer blocks at 28 days

\begin{tabular}{|c|c|c|c|}
\hline $\begin{array}{l}\text { Series } \\
\text { Id. }\end{array}$ & Face Immersed & $\begin{array}{c}\text { IRA } \\
\mathrm{kg} / \mathrm{m}^{2} / \mathrm{min}\end{array}$ & $\begin{array}{l}\text { Avg. IRA } \\
\mathrm{kg} / \mathrm{m}^{2} / \mathrm{min}\end{array}$ \\
\hline \multirow{3}{*}{ GPB-1 } & $230 \mathrm{~mm} \times 150 \mathrm{~mm}$ & 4.9 & \multirow{3}{*}{4.83} \\
\hline & $230 \mathrm{~mm} \times 85 \mathrm{~mm}$ & 4.8 & \\
\hline & $150 \mathrm{~mm} \times 85 \mathrm{~mm}$ & 4.8 & \\
\hline \multirow{3}{*}{ GPB-2 } & $230 \mathrm{~mm} \times 150 \mathrm{~mm}$ & 4.6 & \multirow{3}{*}{4.63} \\
\hline & $230 \mathrm{~mm} \times 85 \mathrm{~mm}$ & 4.7 & \\
\hline & $150 \mathrm{~mm} \times 85 \mathrm{~mm}$ & 4.6 & \\
\hline \multirow{3}{*}{ GPB-3 } & $230 \mathrm{~mm} \times 150 \mathrm{~mm}$ & 4.5 & \multirow{3}{*}{4.5} \\
\hline & $230 \mathrm{~mm} \times 85 \mathrm{~mm}$ & 4.6 & \\
\hline & $150 \mathrm{~mm} \times 85 \mathrm{~mm}$ & 4.4 & \\
\hline \multirow{3}{*}{ GPB-4 } & $230 \mathrm{~mm} \times 150 \mathrm{~mm}$ & 4.1 & \multirow{3}{*}{4.17} \\
\hline & $230 \mathrm{~mm} \times 85 \mathrm{~mm}$ & 4.2 & \\
\hline & $150 \mathrm{~mm} \times 85 \mathrm{~mm}$ & 4.2 & \\
\hline \multirow{3}{*}{ GPB-5 } & $230 \mathrm{~mm} \times 150 \mathrm{~mm}$ & 4.2 & \multirow{3}{*}{4.1} \\
\hline & $230 \mathrm{~mm} \times 85 \mathrm{~mm}$ & 4.1 & \\
\hline & $150 \mathrm{~mm} \times 85 \mathrm{~mm}$ & 4.0 & \\
\hline \multirow{3}{*}{ GPB-6 } & $230 \mathrm{~mm} \times 150 \mathrm{~mm}$ & 4.3 & \multirow{3}{*}{4.16} \\
\hline & $230 \mathrm{~mm} \times 85 \mathrm{~mm}$ & 4.2 & \\
\hline & $150 \mathrm{~mm} \times 85 \mathrm{~mm}$ & 4.0 & \\
\hline
\end{tabular}


The variation of compressive strength of the masonry units with age is indicated in Fig. 1. It can be observed that the compressive strength of the masonry units at the age of 3 days is more than $3 \mathrm{MPa}$, which is quite interesting when it compared to the conventional blocks. This would be sufficient to handle the masonry units for various purposes and also to increase the production at site. The minimum compressive strength of block at 28 days is $3.5 \mathrm{MPa}$ as per IS 1077-1992. The strength of the blocks increased with increase in sodium silicate ratio. The compressive strength varies ranging from 5-23 MPa for the masonry units [26].

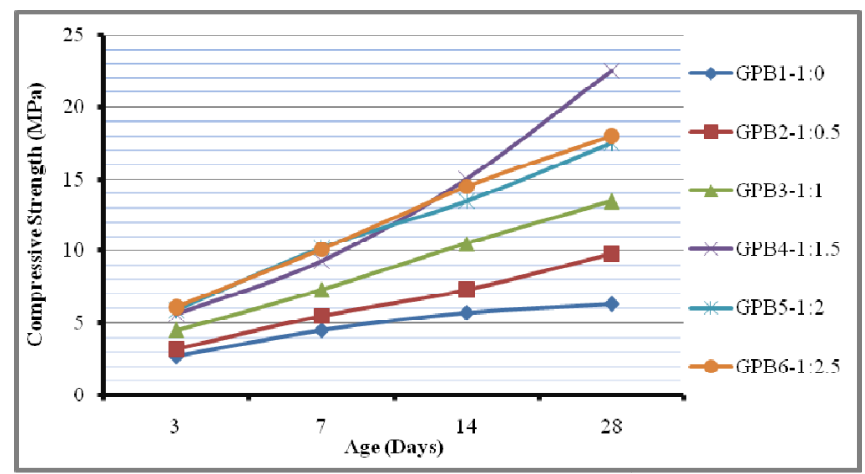

Fig -1: Development of Compressive Strength blocks with age

Scanning Electron Microscope (SEM) image of block is as shown in Fig 2. Microstructure of the image shows the presence of unreacted flyash particles and aluminosilicate gel phases. The unreacted flyash particles were of size less than $2 \mu \mathrm{m}$. Low molarity of alkaline solution may not have influenced by all the fly ash available. There is a possibility of activating these particles at higher molarity and develop higher strength.

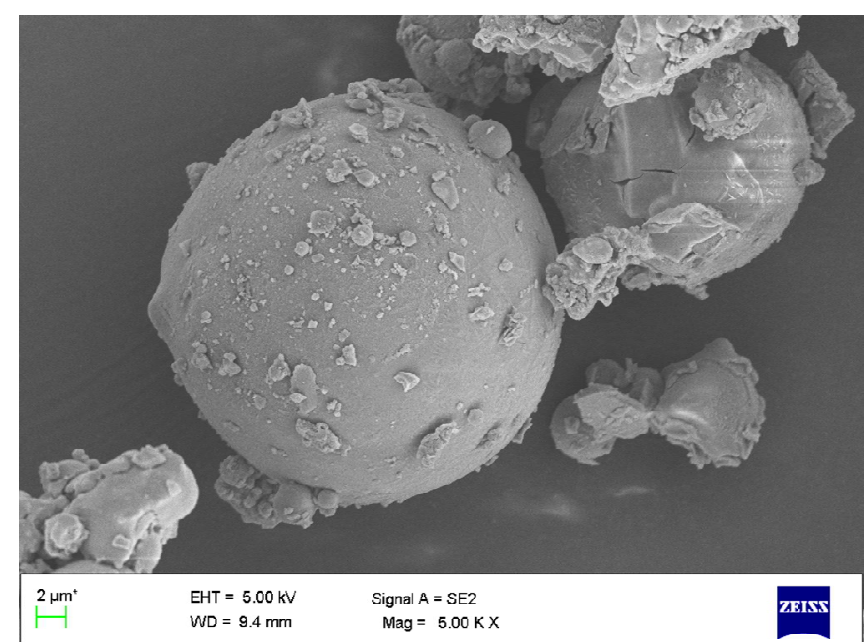

Fig- 2: Scanning Electron Microscope Image of $8 \mathrm{M} \mathrm{NaOH}$ Blocks

Figure 3 shows the X-Ray Diffraction (XRD) results of block. The Material composition of the block is shown in Table 4.

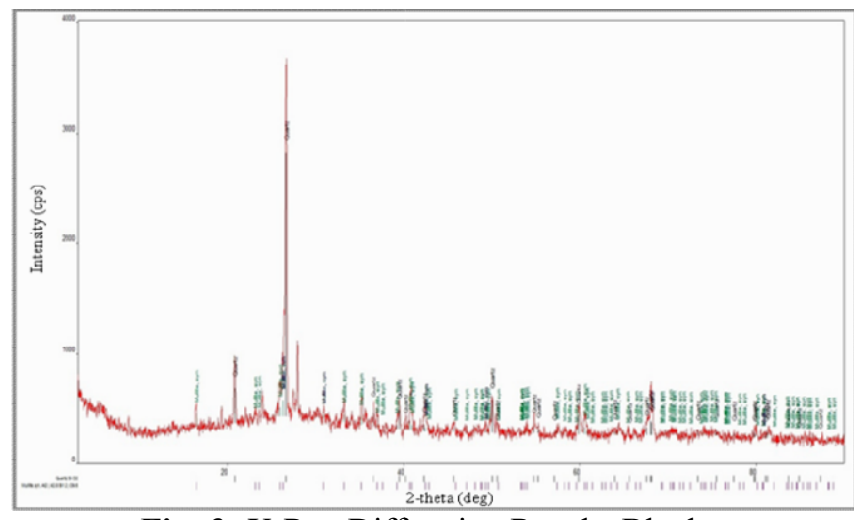

Fig -3: X-Ray Diffraction Results Blocks

Table 4: Material Composition of the Brick

\begin{tabular}{|c|c|}
\hline Phase Name & Content (\%) \\
\hline Quartz & 69 \\
\hline Mullite & 12.2 \\
\hline Gossypol acetic acid & 0.000000 \\
\hline Vaterite & 18 \\
\hline
\end{tabular}

The flexural strength test was done as per IS 4860:1968, the minimum flexural strength of the blocks at 28 days is $10 \%$ of the compressive strength of the masonry units. It is shown in Table 5. It was found that flexural strength was more than $2 \mathrm{MPa}$ and shear bond strength is more than $0.4 \mathrm{MPa}$ which are considerably more due to bonding between fluid, binders and aggregates compared to the traditional cement blocks [26].

Table 5: Flexural Strength of Compressed Bricks at 28 days

\begin{tabular}{|c|c|c|}
\hline Series Id. & $\begin{array}{c}\text { Flexural Strength } \\
{[\mathrm{MPa}]}\end{array}$ & $\begin{array}{c}\text { Shear Bond Strength } \\
{[\mathrm{MPa}]}\end{array}$ \\
\hline GPB-1 & 2.43 & 0.43 \\
\hline GPB-2 & 2.5 & 0.45 \\
\hline GPB-3 & 2.55 & 0.47 \\
\hline GPB-4 & 2.7 & 0.472 \\
\hline GPB-5 & 2.71 & 0.475 \\
\hline GPB-6 & 2.70 & 0.478 \\
\hline
\end{tabular}

The variation of stress and strain was found be similar as that of traditional masonry unit as indicated in Fig.4. The modulus of elasticity of geopolymer masonry block was found to be $9394 \mathrm{MPa}$ at the age of 28 days. This is superior compared to conventional burnt brick [27]. 


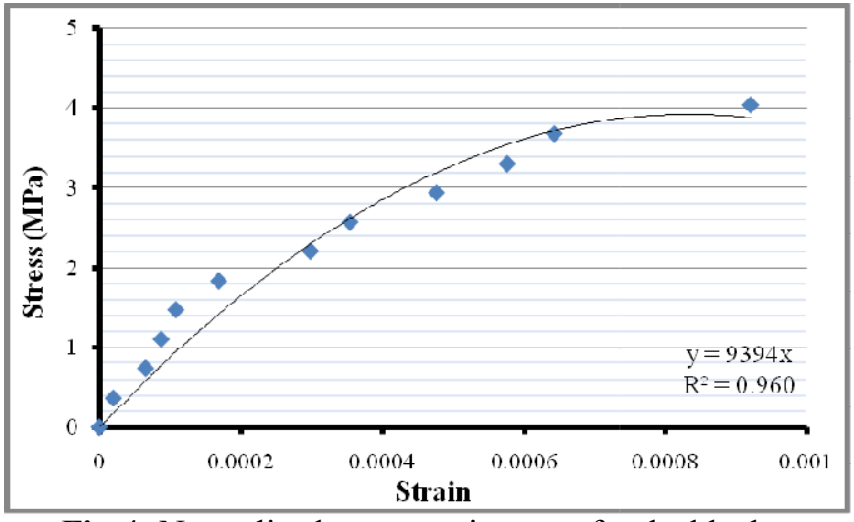

Fig-4: Normalized stress strain curve for the blocks

\section{CONCLUSIONS}

Based on the limited study of geopolymer blocks, the following broad conclusions can be made.

$\checkmark$ The compressive strength of geopolymer block at the age of 3 day was more than $3.5 \mathrm{MPa}$, which makes the user to handle without any serious issues.

$\checkmark$ The water absorption, initial rate of water absorption and modulus of elastic of the units were well within the limits prescribed the relevant codes of practice.

$\checkmark \quad$ The use of geopolymer blocks and mortar are greatly influences to make use of the masonry units.

$\checkmark$ The unreacted flyash particles were of size less than $2 \mu \mathrm{m}$ which is quite finer than cement particles.

$\checkmark \quad$ The flexural strength bond strength is higher than that of regular cement blocks.

\section{ACKNOWLEDGEMENT}

The authors would like to thank the authorities of Jain University-Bangalore for their continuous support and encouragement.

\section{REFERENCES}

[1]. Anita Fódi and István Bódi, Basics of reinforced masonry, Concrete structures, 3(1), pp 69-77 (2011)

[2]. Robert G. Drysdale and Ahmad A. Hamid, "Masonry structures behavior and design", Third edition, Mcmaster University, Hamilton, Ontario (2008).

[3]. Deepasree M Vijay., Poornima A Menon., Fathima Shahanas., "Environmental pollution from brick making operations and their effect on workers", Biomarkers, 4(3), pp 162-166 (2001).

[4]. "Climate change and the cement industry" GCL's Cement Trends-2002, GCL-Environmental special issue, Conference and forum, London, Monday 27 May (2002).

[5]. Joseph Davidovits, "Properties of geopolymer cements", Proceedings of Kiev state technical university conference, Ukraine, pp 131-149 (1994).

[6]. Andri Kusbiantoro, Muhd Fadhil Nuruddin b, Nasir Shafiq b and Sobia Anwar Qazi, "The effect of microwave incinerated rice husk ash on the compressive and bond strength of fly ash based geopolymer concrete", Construction and Building Materials. 36, pp 695-703. (2012).
[7]. Rajamane N. P., Nataraja M. C. and Lakshmanan N., "Applicability of Acceptance Criteria of IS: 456-2000 to GGBS based Self Curing Geopolymer Concrete", Proceedings of International Conference, "Advances in Materials and Structures", ICI- AMAS, Puducherry, India. pp. 370-378. (2011).

[8]. Rajamane N. P., Nataraja M. C., Lakshmanan N. and Dattatreya J. K., "Pull-Out Tests for Strengths of Geopolymer Concretes", Proceedings of International Conference, "Advances in Materials and Structures", ICIAMAS, Puducherry, India. pp. 350-358. (2011).

[9]. R. Anuradha, V. Sreevidya, R. Venkatasubramani and B. V. Rangan, "Relationship between Venugopal K, Radhakrishna Properties and Application of Geopolymer Masonry Units SSRG International Journal of Civil Engineering (SSRG-IJCE) -EFES, ISSN: 2348 -8352, pp 117-119, April (2015).

[10]. K. Vijai, R. Kumutha and B. G. Vishnuram, "Experimental Investigation on Mechanical Properties of Geopolymer Concrete Composites", Asian Journal of Civil Engineering (Building and Housing), Vol. 13, No. 1, pp. 8996 (2012).

[11]. Prabir K. Sarker, Rashedul Haque and Karamchand V. Ramgolam, "Fracture behaviour of heat cured fly ash based geopolymer concrete, ", Materials and Design, 44, pp. 580586 (2013).

[12]. Benny Joseph and George Mathew, "Influence of aggregate content on the behavior of fly ash based geopolymer concrete", Scientia Iranica Transactions A: Civil Engineering, doi:10.1016/j.scient.2012.07.006. (2012). [13]. Saeed Ahmari, Xin Ren, Vahab Toufigh and Lianyang Zhang, "Production of geopolymeric binder from blended waste concrete powder and fly ash", Construction and Building Materials, 35 pp. 718-729. (2012).

[14]. Ali Nazari, "Compressive strength of geopolymers produced by ordinary Portland cement: Application of genetic programming for design", Materials and Design, 43, pp. 356-366 (2013).

[15]. Radhakrishna, Shashishankar A., Udayashankar.B.C and Renuka Devi. M.V., "Compressive Strength Assessment of Geopolymer Composites by a Phenomenological Model", Journal of Reinforced Plastics and Composites, 4 Vol. 29, No. 6, pp 840-852 (2010).

[16]. Radhakrishna, "A Phenomenological Model To ReProportion Geopolymer Compressed Blocks", Concrete Technology Today, vol 7, No. 3 pp.46-48 (2008).

[17]. Radhakrishna, Renuka Devi. M.V. and Udayashankar.B.C. "Use of fly ash in Construction Industry for sustainable development" Journal of Environmental Research and Development, volume 03, pp1211-1221 (2009).

[18]. Radhakrishna, Shashishankar A. and Udayashankar.B.C "Analysis and Assessment of Strength Development in Class F Fly Ash Based Compressed Geopolymer Blocks" Indian Concrete Journal, , Vol 82, No.8.pp.31-37 (2008).

[19]. Radhakrishna, Shashishankar A. and Udayashankar. B. C., Phenomenological Models to Proportion Phenomenological Model to Re-Proportion geopolymer 
Compressed Blocks. $3^{\text {rd }}$ Conference on Our World in Concrete \& Structures: 25 - 27 August 2008, Singapore.

[20]. Radhakrishna, Manjunath GS., C Giridhar and Mahesh Jadav " Strength Development in Geopolymer pastes and Mortars", International Journal of Earth Sciences, ISSN 0974-5904, Volume 04, No 06 SPL, pp. 830-834 (2011).

[21]. Abdullah shahbaz khan, Ram panth, Gagan Krishna R.R, Suresh G. Patil "Structural Performance of Concrete by Partial Replacement of Cement with Hypo Sludge" International Journal of Emerging Technologies and Engineering (IJETE) ISSN 2348 -8050 Volume 1 Issue 7 (August 2014).

[22]. Andrew M Dunster "Characterization of Mineral wastes, Resources and Processing Technologies-Integrated Waste management for the production of construction material- Case study on Paper Sludge ash in portland cement manufacture, WRT 177 / WR0115, October-(2007).

[23]. Anastasios Drougkas, Pere Roka, Clement Molins, "Compressive strength and elasticity of pure lime mortar masonry", Journal of materials and structures, Vol-49, issue3, pp 983-999, march (2016).

[24]. Mojmir Uranjek and violeta Bokan-Bosiljkov, "Influence of freeze-thaw cycles on mechanical properties of historical brick masonry", Journal of construction and building materials 84, pp 416-428. (2015).

[25]. Paulina Faria, Tânia Santos, Jean-Emmanuel Aubert, "Experimental characterization of an earth eco-efficient plastering mortar", Journal of materials in civil engineering, ISSN (online): 1943-5533, pp-116-120, Volume 28, Issue 1 (January 2016).

[26]. G. Sarangapani, B. V. Venkatarama Reddy and K. S. Jagadish "Structural characteristics of bricks, mortars and masonry" Journal of Structural Engineering. No.29-11, pp. 101-107, July-September (2002).

[27]. G. Sarangapani, B. V. Venkatarama Reddy and K. S. Jagadish "Brick-Mortar Bond and Masonry Compressive Strength" Journal of Materials in Civil Engineering. Vol. 17, No. 2, pp. 229-237, April (2005).

\section{BIOGRAPHIES}

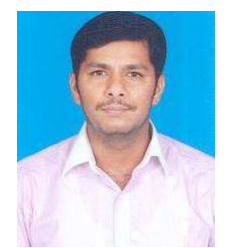

Prof. Venugopal. K was born on 14th August 1982 in Karnataka state of India. $\mathrm{He}$ obtained bachelor degree in Civil Engineering from Visvesvaraya Technological University, India during 2007. He completed ME in Construction Technology during 2009 from Bangalore University, Bangalore, Karnataka state of India, presently pursuing his $\mathrm{Ph} . \mathrm{D}$ in Concrete Technology under Jain university, Bangalore, India.

He is Presently serving as Associate Professor and Head, Department of Civil Engineering at SEA College of Engineering and Technology, Bangalore, India. He has over 08 years of teaching experience in various Civil Engineering subjects. He has published $08+$ research papers in various journals/Conferences.
He is life member of Indian Society of Technical Education (LM-101997), Association of Consulting Civil Engineers. (LM-3774L), Indian Concrete Institute. (LM-10472). His areas of interest include Masonry structures and fly ash composites.

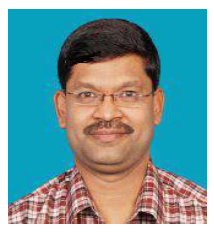

Dr. Radhakrishna obtained bachelor degree in Civil Engineering from Bangalore University, India during 1990. He completed $M$ Tech in Structural Engineering from Visvesvaraya Technological University, Belgaum later Ph.D in Concrete Technology in 2010 from the same university.

$\mathrm{He}$ is Presently Associate Professor at R V College of Engineering, Bangalore, India. He has over 25 years of teaching experience in various Civil Engineering Programs. $\mathrm{He}$ has published $70+$ research papers in various journals/conferences. He has co-authored a book on Eco efficient masonry blocks published by Elsevier in 2015 . He has delivered invited talks at various places in India and abroad.

$\mathrm{He}$ is the life member of Indian Concrete Institute, Association of Consulting Civil Engineers (I), Swadeshi Vignana Andolana and Institution of Engineers. He is the reviewer for several international journals and has guided two Ph.D scholars. Currently he is Editor-in-Chief for International Journal of Research in Engineering and Technology. Presently he is guiding five Ph.D scholars. His areas of interest are alternative building materials with particular reference to geopolymers, FaL-G and high volume fly ash concrete. 